Ekaterina V. Zaytseva', Mihail I. Kuryachiy²,

DOI:10.25045/jpit.v11.i1.04

Vyacheslav V. Kapustin ${ }^{3}$

Department of Television and Control Tomsk state university of operation systems and radio electronics, Tomsk, Russia

1'katerinka_zev@mail.ru, ${ }^{2}$ kur@tu.tusur.ru, ${ }^{3}$ peregnun@mail.ru

\title{
PHOTOELECTRIC CHARACTERISTICS OF ACTIVE-PULSE TELEVISION MEASURING SYSTEM
}

\author{
Received: 29.01.2019 \\ Revised: 30.03.2019 \\ Accepted: 28.06.2019
}

Technical vision systems are becoming more widespread, capable of effectively solving the problems of searching, detecting and recognizing interest objects in difficult visibility conditions (fog, haze, dust, snowfall, etc.) at present, in science and technology. The main advantages of active-pulse television measurement systems include the elimination of backscatter interference and the significant reduction in light interference of natural and artificial nature. This paper presents the dependences of calculating the basic photoelectric characteristics of active-pulse television measuring systems and the results of estimating the distance to the objects of observation depending on the conditions of the propagation medium. The analysis of the photoelectric characteristics is performed for the sensors on two types of photoelectric converters: CCD and CMOS. A comparative analysis of the dark current in CCD and CMOS matrices is carried out. Based on the results of the analysis and the presented dependencies, conclusions are drawn and recommendations are given for choosing a sensor for active-pulse television measuring systems.

Keywords: illumination, brightness, CMOS-matrix, electron-optical converter.

\section{Introduction}

The main purpose of the active-pulse television measuring systems (APTMS) is the observation in poor vision conditions (fog, haze, dust, snowfall, etc.). The laboratory model of the APTMS is developed for the experimental studies at the Department of Television and Control.

\section{Aims and tasks of research}

There is a possibility of video surveillance in the conditions of high temperatures and pressures in oil production. Here, high-temperature APTMS can be used to monitor the state of wells, study their debit, as well as to monitor color marks specifically injected into the oil-bearing formation for determining the direction of fluids movement in it. APTMS operating conditions for oil production implies the high temperature up to $135-150^{\circ} \mathrm{C}$, high pressure, as well as severe weight and size restrictions.

The main task in the development of any APTMS is the choice of photodetector. There are two kinds of photodetector structures: matrix charge-coupled devices (CCD) and sensors based on the complementary metal oxide semiconductor (CMOS) [1-5]. Each of the structures has photovoltaic characteristics. We present the main ones.

The resolution of the photodetector is primarily determined by the number of photosensitive elements and their geometric size. In contrast to CCD technology, CMOS technology allows using fairly simple tools to organize a photo detector containing a very large number - tens of millions of pixels and having a very large crystal area, for example, coinciding with the frame size of a standard photo film. This is due to the fact that the probability of capturing a fatal defect quickly increases with the size of a CCD transducer. In a CMOS sensor, such a defect will cause the defeat of a single pixel, the value of the video signal of which can be interpolated by neighboring elements, including directly in the sensor itself. In matrix CCDs, such a defect very often leads to the inoperability of the entire converter as a whole. Thus, the yield of photo detectors made by CMOS technology, especially with a large crystal area, is significantly higher than for CCD technology.

The sensitivity of the photodetector is determined by the collection coefficient of the luminous 
flux, quantum efficiency and intrinsic noise. The presence of a large number of transistors in each pixel leads to a decrease in the utilization rate of the luminous flux in CMOS sensors, but the use of welldeveloped microlens technology located on a photodiode (on-chip-microlenses) in matrix CCDs with a line-wise transfer of microlenses allows for very high acquisition ratios in perspective to $100 \%$.

The use of optimized structures of modern photodiodes as a photosensitive element maximizes the quantum yield, and the presence of an active amplifier built into the pixel theoretically allows for a lower noise level than in CCD structures. Also, a beneficial factor affecting the reduction of intrinsic noise is the reduction of the video signal-processing band when using the parallel processing of the video signals of all pixels of a row or the entire photodetector. In already existing CMOS sensors with active pixel, the conversion rate of charge into voltage can reach hundreds of microvolts per electron compared to tens of microvolts per electron in the best photodetectors on a CCD.

However, the lack of sophistication of the technology manifested, including the inability to create a megapixel array of low-noise transistors leads to the fact that the CMOS noise of photodetectors still exceeds the noise of CCD converters, and while their sensitivity with equal factors, such as the accumulation time and the size of the photosensitive element, is still an inferior (about order) sensitivity of the CCD.

The spectral sensitivity characteristics are generally identical to the characteristics of a matrix CCDs and primarily determined by the type and characteristics of the applied silicon photosensitive element - MOS capacitance or photodiode. At the same time, CMOS sensors are known in which the reading circuits are made using silicon technology, and special layers are used as photosensitive elements. This structure allows you to create CMOS the photodetectors of the infrared range.

The dynamic range of CMOS sensors is determined by the maximum charge packet accumulated in the photosensitive elements and the read noise or geometric noise. From this point of view, the dynamic range of the CMOS sensor is comparable to the dynamic range of the CCD with the same pixel size. However, the possibility of varying the characteristics of the photosensitive element and reading circuits allows a user to build a CMOS sensor with a logarithmic dependence of the output signal on the illumination and bring the working dynamic range to 132 $\mathrm{dB}$ [6]. A well-known method of expanding the dynamic range in a matrix CCD is the summation of the charge packets of neighboring pixels horizontally and vertically directly on the converter until the moment of reading [7]. In CMOS sensors with coordinate addressing, such summation (binning) is difficult, but the sensors are known in which the summation of an arbitrary number of charge packets of neighboring elements can be organized [8].

Modern matrix CCDs, when charge packet moves to the output device, can pass through a macro distance of tens of millimeters. In this case, the transfer rate is usually limited by the clocking frequency of the phase electrodes of the output register and rarely exceeds $40 \mathrm{MHz}$. A further increase in the transfer frequency leads to an increase in the inefficiency and the power consumption and to a decrease in the control capacity, etc. This restriction of the reading frequency leads to the corresponding restrictions on the achievable frame frequency and requires an increase in parallel reading methods and subsequent image stitching. In CMOS sensors, sampling frequencies of 50 $\mathrm{MHz}$ pixels are typical, and this frequency exceeds $100 \mathrm{MHz}$ in best samples. Taking into account the fact that the parallelization of outputs in CMOS sensors is implemented more easily than in matrix CCDs, it is simpler task to achieve high personnel frequencies and, accordingly, better dynamic characteristics, for CMOS. Currently, a number of companies implementing the frame rates above $1 \mathrm{kHz}$ are on the high-speed camera market.

\section{Methods of solving and approbation of results}

An important parameter in the high-temperature mode of the photodetector is the level of dark current. The dark current is caused by the thermogeneration of electrons in the depleted region of the silicon substrate photodetector and represents the number of dark electrons collected in a pixel 
during the accumulation time. The expression for the number of electrons of the dark current is

$$
n_{T T}=\frac{j_{T T} T A_{e}}{q},
$$

$q=1,6 \cdot 10^{-19} C$ electron charge;

$j_{\mathrm{TT}}-$ dark current density ;

$A_{e}=\Delta x \Delta y-$ area of the photosensitive element;

$T$ - accumulation time [8].

In a matrix $\mathrm{CCD}, \mathrm{F}$, dark current is generated in $\mathrm{PD}$ photodiodes and in vertical shift registers VCCD. The accumulation can only be managed in the PD area, and the accumulation time in VCCD is constant and equal to the accumulation time of the field - $20 \mathrm{~ms}$ or to frame accumulation time - $40 \mathrm{~ms}$. That is, as the temperature increases, the total dark current level always increases regardless of the accumulation time due to the reading time. In CMOS sensors, the dark current is generated only in the photodiode; that is, it is possible to reduce the level of dark current by reducing the accumulation time in the electronic shutter mode [3].

Thus, an photodetector on a CMOS sensor should be used for a high-temperature fuel assembly under development, since the dark current level under equal temperature conditions is lower in CMOS sensors than in a CCD.

The integrated sensitivity of CMOS photodetectors, that is, the dependence of the useful video signal on the illumination is determined by the formula [9]:

$$
Q_{s}=E_{\mathrm{KMOS}} \frac{K T A_{\mathrm{e}}}{k} \frac{\int_{\lambda_{\text {min }}}^{\lambda_{\max }} S(\lambda) \Phi^{\prime}(\lambda) d \lambda}{\int_{\text {mix }}^{\lambda_{\max }} v(\lambda) \Phi^{\prime}(\lambda) d \lambda},
$$

$\boldsymbol{K}$ - transmission factor;

$\Phi^{\prime}(\lambda)$ - relative spectral distribution of the incident light flux;

$S(\lambda)$ - spectral sensitivity of the video camera;

$v(\lambda)$ - relative spectral response of the electronic flow of radiation of the radiation source;

$$
k=\frac{\int_{0}^{\infty} y(\lambda) V(\lambda) d \lambda}{\int_{0}^{\infty} y(\lambda) d \lambda} ;
$$

$y(\lambda)$ - relative spectral sensitivity of the eye.

Using the refined expression to determine the optical transmission coefficient in terms of brightness, we obtain an expression in general form for determining the integrated sensitivity of TV systems on a CMOS photodetector $[10,11]$ :

$$
Q_{s}=B_{\mathrm{o}} \frac{2 \pi \tau_{\mathrm{o}}}{\beta^{2}}\left[1-\frac{1}{\sqrt{1+d^{2}}}\right] \frac{K T A_{\mathrm{p}}}{k} \frac{\int_{\lambda_{\text {min }}}^{\lambda_{\max }} S(\lambda) \Phi^{\prime}(\lambda) d \lambda}{\int_{\lambda_{\min }}^{\lambda_{\max }} v(\lambda) \Phi^{\prime}(\lambda) d \lambda},
$$


$B_{\mathrm{o}}$ - object brightness;

$$
d=\frac{D_{i n p} \beta}{2 f_{\mathrm{o}}(1+\beta)}
$$

$\beta$ - module matching the magnification optics (linear scale image);

$\tau_{\mathrm{o}}$ - transmittance lens matching;

$D_{\text {inp }}$ - diameter of the input matching lens;

$f$ - lens focal length matching system.

Experimental studies of APTMS are carried out in a large aerosol chamber (LAC) of the Institute of Optics and Atmosphere named after V.E. Zueva. Three radial worlds installed at distances of $15 \mathrm{~m}$ (world 1), $18 \mathrm{~m}$ (world 2) and $21 \mathrm{~m}$ (world 3) are used as the objects of observation.

Figure 1 shows the image of the location of the measuring world in the LAC with the areas of measurement marked on them.

To achieve the aims and perform the tasks of the research, experimental measurements are implemented using a special measuring complex (figure 1).

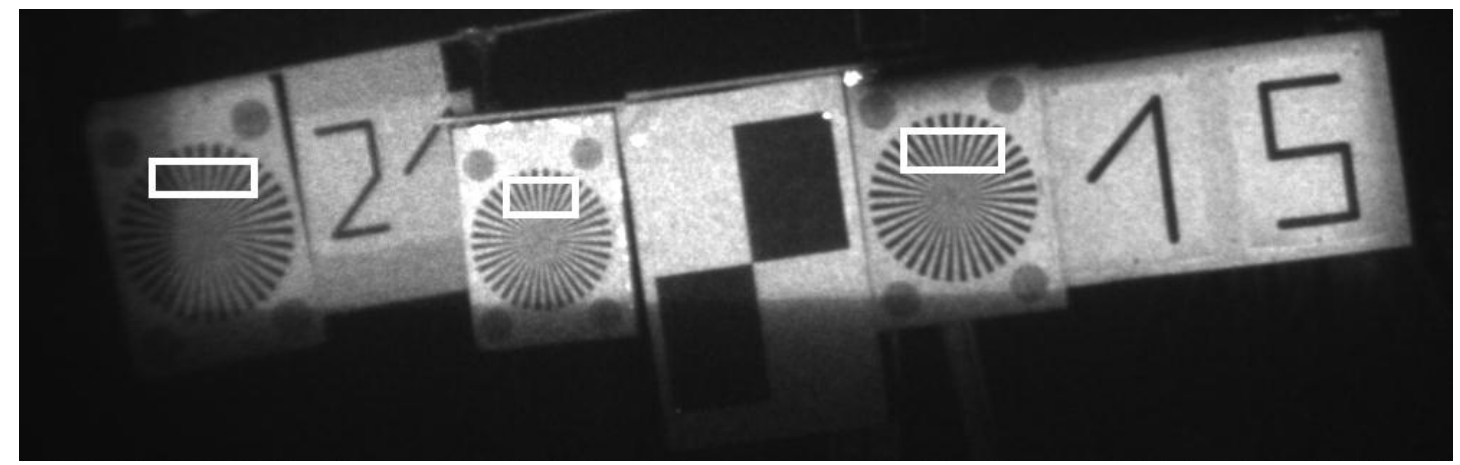

Figure 1. Location of the measuring world and change areas on them

Figure 2 shows the dependence of the average brightness levels in the measurement areas on the gating delay of the photodetector with the following AI TIS parameters: the duration of the illumination pulse is $40 \mathrm{~ns}$, the gating pulse duration of the photodetector is $60 \mathrm{~ns}$.

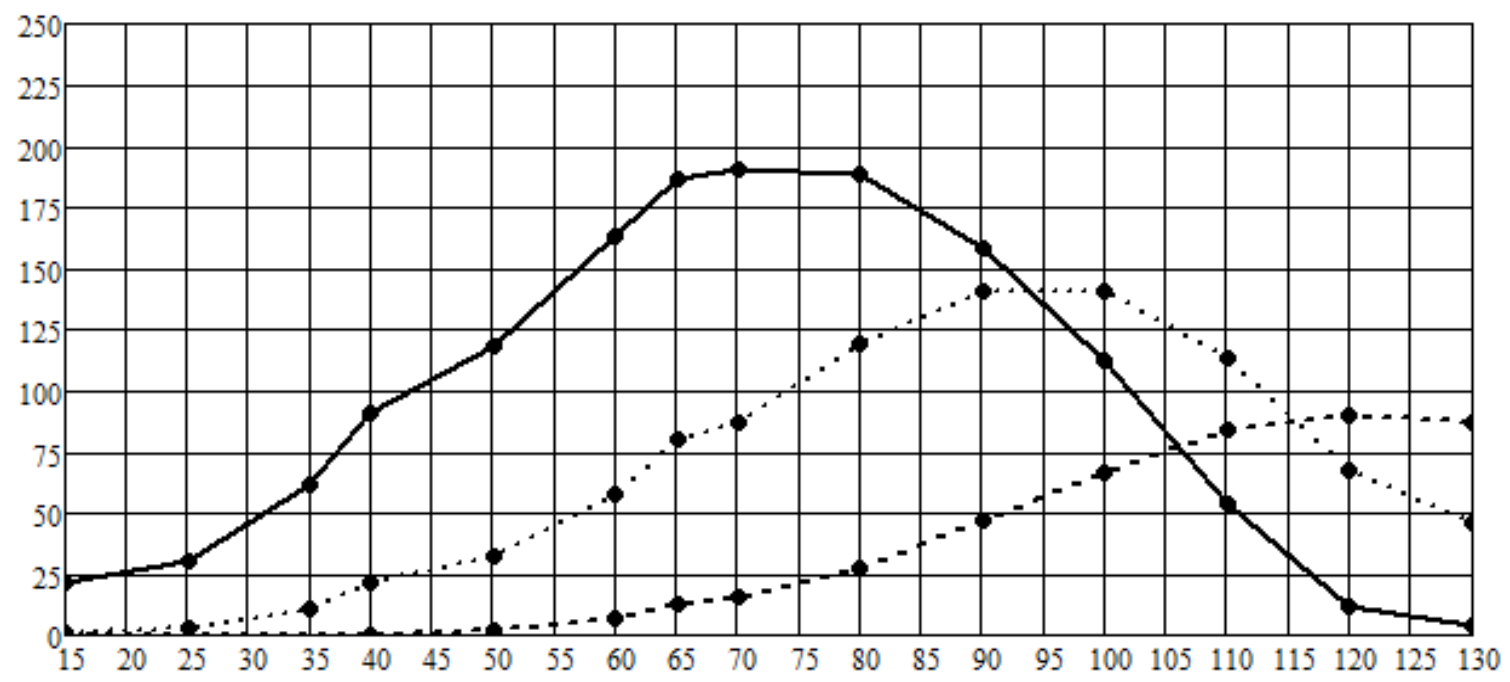

Figure 2. Dependencies of average quantization levels on gating delay 


\section{Conclusion}

1. The given dependence showed that, in the $\mathrm{CCD}$, the main contribution to the dark charge was made by the vertical transfer registers. For CMOS sensors, the level of the number of dark electrons was no more than a few hundred and could be reduced using a mode of operation with a reduced accumulation time.

2. Thus, to build high-temperature fuel assemblies, CMOS sensors with both a running and global shutter could be used.

3. Experimental graphs of the dependence of the average quantization levels in AI TIS vision zones took into account the peculiarities of the processes of radiation propagation in the space which introduce errors in measuring the distance to objects. The measurement error of the distance to objects was reduced according to the square of the distance to the object of observation and could be adjusted according to the results of the system calibration

4. Evolving to video systems on a chip CMOS cameras determined the most promising direction of video informatics - the creation of intelligent television and computer systems that would allow the real-time technical and artificial vision systems to be realized comparable in performance to the biological vision and significantly superior to its speed.

The work was supported by the Russian Ministry of Science and Higher Education for Project No. 8.9562.2017 / 8.9 and the RFBR grant No. 16-47-700939.

\section{References}

1. Mantsvetov A.A., Tsitsulin A.K. Television cameras on CMOS photodetectors. Issues of radio electronics. Television Technology Series, 2006, no 2, pp. 70-89.

2. Umbitaliev A.A., Tsitsulin A.K., Mantsvetov A.A., etc. Control of the mode of accumulation in solid-state photodetectors // Optical Journal, 2012, no. 11, pp. 84-92.

3. Tsitsulin A.K. and others. Solid-state cameras: the accumulation of information quality. - SPb., Publishing house of Saint-Petersburg Electrotechnical University "LETI", 2014, 234 p.

4. CMOS Imagers. From Phototrunsduction to Image Processing. Edited by O. Yadid-Pecht and R. Etienne-Cummings. Kluwer Academic Publishers, 2004, 241 p.

5. Bykov R.E., Freier R., Ivanov K.V., Mantsvetov A.A. Digital image conversion M.: Hotline - Telecom, 2003, 228 p.

6. Stoppa D., Simoni A., Gonzo L., Gottardi M. Novel CMOS image sensor with a 132-dB dynamic range // IEEE journal of solid-state circuits, 2002, vol. 37, no 12, pp. 1846-1852.

7. Mantsvetov A.A., Mikhailov V.A., Eisengardt G.A. Characteristics of matrix-type DFDDs in charge charge summation mode // Communication technology. Ser. Television equipment, 1990, vol. 2. pp. 26-33.

8. Morton Z., Artyomov E., Rivenson Y., Levi G., Yadid-Pecht O. Scan Based Real-Time Variable Resolution CMOS Image Sensor // IEEE transactions on circuits and systems for video technology, vol. 15, no 7, pp. 947-952.

9. Nosov Yu.R., Shilin V.A. Fundamentals of physics of charge-coupled devices , M.: Science, 1986, $318 \mathrm{p}$.

10. Mantsvetov A. A Sensitivity of CMOS photodetectors with an active pixel // Questions of radio electronics. Ser. Technique of television, 2014, no 2. pp. 18-24.

11. Pustynsky I.N. Utochneniye zavisimosti osveshchonnosti ob"yekta $\mathrm{v}$ televizionnykh datchikakh [Clarification depending illumination optical image from the illumination of the object in the television sensors] // Reports of the Tomsk State University of Control Systems and Radio Electronics, 2009, no 1, pp. 36-39. 
UOT 004.04, 621.397.2

Zaytseva Yekaterina V. ${ }^{1}$, Kuryaçiy Mixail I. ${ }^{2}$, Kapustin Vyaçeslav V. ${ }^{3}$

Tomsk Dövlət İdarəetmə Sistemləri və Radioelektronika Universiteti, televiziya və idarəetmə kafedras1

${ }^{1}$ katerinka_zev@mail.ru, ${ }^{2}$ kur@tu.tusur.ru, ${ }^{3}$ peregnun@mail.ru

\section{Fəal-impulslu televiziya ölçmə sistemlərinin fotoelektrik xarakteristikaları}

Hazırda mürəkkəb görmə şəraitində (duman, tüstü, toz, qar və s.) maraq kəsb edən obyektlərin axtarışı, aşkarlanması və tanınması məsələlərini effektiv şəkildə həll edən texniki görmə sistemləri elm və texnika sahələrində geniş yayılmaqdadır. Fəal-impulslu televiziya ölçmə sistemlərinin əsas üstün cəhətlərinə əks səpələnmə maneəsini aradan qaldırması, təbii və süni işıq maneələrini əhəmiyyətli dərəcədə zəiflətməsi imkanları daxildir. Tədqiqat işində fəal-impulslu televiziya ölçmə sistemlərinin əsas fotoelektrik xarakteristikalarının hesablanması üçün asılılıqlar və yayılma mühitinin şəraitindən asılı olaraq müşahidə obyektlərinə qədər olan məsafənin qiymətləndirilməsinin nəticələri təqdim edilmişdir. Sensorlar üçün fotoelektrik xarakteristikaların analizi iki növ fotoelektrik çeviricilər - PZS və KMOP üzrə aparılmışdır. PZS və KMOP matrislərində zəif cərəyanın sızmasının müqayisəli analizi aparılmışdır. Aparılmış analizin nəticələrinə və təqdim edilmiş asılılıqlara əsasən nəticə çıxarılmış və fəal-impulslu televiziya ölçmə sistemləri üçün sensorların seçilməsi üzrə tövsiyələr verilmişdir.

Açar sözlor: faal-impulslu televiziya ölçmə sistemlari, KMOP, PZS müşahidə şaraiti, işıqlanma daracasi, zaif carayan, kvantlaşdırma saviyyalari.

\section{УДК 004.04, 621.397.2}

Зайцева Екатерина В. ${ }^{1}$, Курячий Михаил И. ${ }^{2}$, Капустин Вячеслав В. ${ }^{3}$

Кафедра телевидения и управления, Томский государственный университет систем управления и радиоэлектроники

11katerinka_zev@mail.ru, ${ }^{2}$ kur@tu.tusur.ru, ${ }^{3}$ peregnun@mail.ru

\section{Фотоэлектрические характеристики активно-импульсных телевизионных измерительных систем}

В настоящее время в науке и технике все более широкое распространение получают системы технического видения, способные эффективно решать задачи поиска, обнаружения и распознавания объектов интереса в сложных условиях видимости (туман, дымка, пыль, снегопад и т.д.). Основными достоинствами активно-импульсных телевизионных измерительных систем являются устранение помехи обратного рассеивания и значительное ослабление световых помех естественной и искусственной природы. В данной работе представлены зависимости для расчета основных фотоэлектрических характеристик активно-импульсных телевизионных измерительных систем и результаты оценки расстояния до объектов наблюдения в зависимости от условий среды распространения. Анализ фотоэлектрических характеристик произведен для датчиков на двух типах фотоэлектрических преобразователей: ПЗС и КМОП. Проведен сравнительный анализ протекания темнового тока в ПЗС и КМОП-матрицах. По результатам анализа и представленных зависимостей сделаны выводы и даны рекомендации по выбору датчика для активно-импульсных телевизионных измерительных систем.

Ключевые слова: активно-импульсные телевизионные измерительные системы, КМОП, ПЗС-условия наблюдения, освещенность, темновой ток, уровни квантования. 